\title{
土地利用図の色調パターンの認識*
}

$\begin{array}{ccc}\text { 森 忠 } & \text { 次** } \\ & \text { 星 } & \text { 仰*** }\end{array}$

\section{Pattern Recognition by the Colour Tone of Land Use Map.}

by Chuji Mori, Takashi Hoshi

\begin{abstract}
Introduction: In order to recognize the parrerns represented in a map, picking out of distribution patterens in the map has to be done as pre-processing. Quantitization method was used to pick up the distribution patterns and B. G. R. and B. W. methods are applied for quantitization. Picking out of colour tone distributions was carried out by applying this method. The results show that the accuracy of this method is farily good. But we, also, find some misrecognitions and luck of similitude of patterns between original and obtained figures. In this paper, so, improvement of accuracy are attempted by changing the scale of colour slide obtained from the original map and by increasing nomber of sampling points. As another processing technique, continuous tone negative film separeted each colour tone in the original map is investigated.
\end{abstract}

As these results, it is clear that distribution patterns represented by several colour tones are able to pick up fairly well by B. G. R. and B. W. method, and they will also be picked out simply by using B. G. R. method only.

緒言：地図パターンを認識するには，前処理として 分布パターンの抽出を可能にしなければならないの で，分布パターンの抽出を量子化 ${ }^{1)}$ にって実施する ことにした。量子化の方法は，B.G.R. 法と B.W. 法 を適用することにする。

B.G.R. 法と B.W. 法の組合せによって一部の色調

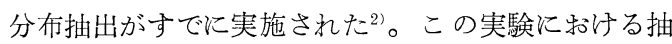
出精度はかなり高い。しかし，パターンの認識の誤認 が多く原地図パターンと抽出パターンの対応性に欠け ていた。そこで，これらの対応性を戦密にするため に，地図をカラースライドに変換する尺度を変え，サ ンプリング数を増して精度の向上をはかった。また， 別法として原寸地図の測定により各色調ごとの分布を 分離させた連続階調ネガ写真を作成することができ た。この結果， B.G.R. 法と B.W. 法を組合せること によって，各色調ごとのパターンを抽出できることが 明らかとなった。また，今後の色調別分布抽出に対し ては, B.G.R. 法のみで分布抽出の可能性のあること

* 一部写真測量学会 (昭和 47 年 5 月) で発表。

** 京都大学工学部交通土木工学教室。

*** 和歌山工業高等専門学校土木工学教空。

「写真測量」Vol. 11 No. 4 1972年
を示したことになる。

\section{1. 概 説}

地図などの平面資料の色調別のパターンを認識させ るには，基本的に下記の 2 点を考慮しなければならな い。すなわち，平面資料の位置の決定法と決定された 位置の色調の認識である。前者に対しては, メッシュ 法を適用することにし，後者に対しては，光の持つス ペクトルを利用して色調別に数值で置き換えることに した。ここでは，上記 2 点を解決させるために処理シ ステムならびに情報を抽出するためのメッシュ法の基 本的概念について述べるとともに，測定資料の編集な ぞの適応性を考慮し，標準メッシュ法を設定すること にした。この標準メッシュ法によるデータは，A-D 変換の順換性・保管性拉よび再現性などを考慮しつつ 桁を最小にし，かつ 3 次元配列で表現することにし， 汎用性を重視した。また，情報を抽出する際のメッシ ュ間隔は，サンプリング密度と密接な関係にあるた め, 処理計画に打いてサンプリング密度を決定するの に役立てることを目的として，2種類のデンシトメ一 タ（平面式片ピッチ型と同形式両ピッチ型）について 
のサンプリング密度を算出する関係式を導いた。

分布抽出の要求精度が高い場合に備えた原寸地図を 色分解する方法と計測処理条件の制限などから原寸地 図の測定が不可能な場合に備えた地図を縮小したカラ ースライド測定法が必要と思われるので, これら 2 種 の実験を試みた。これらの実験から分布面積の抽出・ メッシュ位置のずれなどを含めた分布抽出法に関する 考察を加えた。

\section{2. 情報抽出単位の基本的概念}

地図上のパターン分布を 3 色分解測 定法 (B.G.R. 法）あるいは濃淡測定法 (B.W. 法) などで抽出した ときの抽出面積 $\vec{s}$ は, 地図上の分布面積 $s$ に充分近似

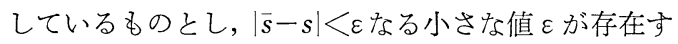
るものと仮定する。また地図上に分布している面積 $s$ は，それに応ずる地表面上の面積 $S$ と一義的な換算定 数によって対応させることが可能であるとする。そう

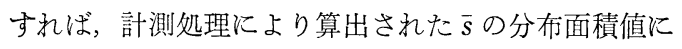
よって $S$ の近似值 $\bar{S}$ を求めることができる。このよ らな仮定を前提として，1枚の地図より $\bar{s}$ を抽出する 場合, 1 枚の地㘠上のパターンに応じて最適な抽出単 位面積を決定しなければならない。このとき，広範囲 の地域をミクロに調查したり：ミクロなデータとマク ロなデータを一定の基準に統一する場合, 情報抽出の ための単位面積の標準化を一般化して括く必要があ る。そこで, 地図上のパターン分布を抽出するため にここでは標準メッシュを設定することにした。測 定点を永久に保存したり再現することを考慮に入れ れば,メッシュを経緯度座標あるいは新平面直角座標 により区切ることが望ましいので，標準メッシュを緯 度 $3^{\prime \prime}$, 経度 $4.5^{\prime \prime}$ の間隔で区切ることにした。緯度 3 " 経度 4.5 ”で囲まれる面積は地上で約 $100 \times 100 \mathrm{~m}^{2}$ に相当 する。この寸法の標準メッシュによれば, 1：30,000 の地図上では約 $3.3 \times 3.3 \mathrm{~mm}^{2}$ に相当する。マクロ調 查によりメッシュ間隔を広く取りたい場合には，上記 緯度, 経度の間隔を整数倍して最適メッシュ間隔を決 定すればよい。

\section{3. 情報抽出位置とサンプリング数}

地図の各色調別分布がある程度の平面的広がりを持 っているときは, プラニメータなどの器材を使用して 分布抽出を算出することもできるが, 細かい多数の点 状によって表現されている場合にはプラニメータなど の器材を使用しえないことがある。B.G.R.法や B.W. 法によれば，このような場合にもパターン分布の測定 が可能であり，これらの方法は単に自動処理できると いら利点ばかりでなく抽出対象の広さをも含んでいる
とえる。ところで, この B.G.R. 法や B.W. 法を使 明した場合, 分布抽出值の抽出精度が問題であり, サ ンブリング密度によって精度が変ってくる。したがっ て, 地図のバターン分布を抽出する計測計画の立案に 際してサンプリングの数をどの程度にすべきか検討す る必要がある。計測計画に必要とされるサンプリング 間隔は, 図上のバターンの形状や大ささなどによって 判断されるべきものであって，数量化した法則により 表現することが現在のところ困難とされ, 定性的視覧 判定を必要としている。乙かし, 計測処理機械の性能 に基づく要因により適切なサンプリング数およびメッ シュ間隔が定まるものであるから，最適標準メッシュ に適応した処理機械の選定あるいは適応した処理機の 作成が必要とされる。

ここでは, 平面式片ピッチ櫛型運動をするデシント メータおよび両ピッチ型のデンシトメータを利用した 場合にかぎってのサンプリング数Nの関係式を以下に 示す。

(a) 平面式片ピッチ型オートデンシトメータ

情報抽出位置を一定間隔にした場合のサンプリング 数 $N$ を決定する要因は, 測定資料の寸法, データレコ 一ダの入力速度 $v_{\mathrm{IN}}, \mathrm{AD}$ 変換機の周波数 $f$ (以上 $N$ に比例する), デンシトメータ速度 (順速度 $V$, 逆速度 $V_{x}$ ), データレコーダ出力速度 vouT (以上 $N$ に逆比 例）およびピッチ移動時間 $t_{0}$ などである。

平面資料 $X$ 万向に 1 行往復する時間 $T_{1}$ のサンプリ ング数を $N_{X}$ で表わせば，次式を得ることができる。

$$
N_{X}=\left(L_{x} / V+L_{x} / V_{x}+t_{0}\right)\left(v_{\text {IN }} / v_{\text {OUT }}\right) f
$$

平面矩形 $n$ 行スキャン時の総サンプリング数を $N_{X Y}$ で表わすと次式となる。

$$
\begin{aligned}
N_{X Y}=\sum_{i=1}^{n} N_{X}= & n\left\{L_{x}\left(V+V_{x}\right) /\left(V \cdot V_{x}+t_{0}\right\}\right. \\
& \left(v_{\text {IN }} / v_{\text {OUT }}\right) f
\end{aligned}
$$

式(1)(2)より有効サンプリング数 $N_{x}, N_{x y}$ は次 式となる。

$$
\begin{gathered}
N_{x}=l_{x} \cdot v_{\mathrm{IN}} \cdot f /\left(V \cdot v_{\mathrm{OUT}}\right) \\
N_{x y}=\sum_{i=1}^{n} N_{x}=n \cdot l_{x} \cdot v_{\mathrm{IN}} \cdot f /\left(V \cdot v_{\mathrm{OUT}}\right) \\
\text { ただし }, \quad n: Y \text { 方向スキャン数。 } \\
l_{x}: X \text { 方向の測定資料の有効幅。 } \\
l_{y}: Y \text { 方向の測定資料の有効幅。 } \\
L_{x}: \text { デンシトメータのX方向移動距離。 } \\
L_{y}: \text { デンシトメータの } Y \text { 方向移動距離。 }
\end{gathered}
$$

また，サンプリング間隔 $b_{X}, Y$ 方向スキャン間隔 $b_{Y}$ とすると次式を得る。

$$
\begin{gathered}
b_{X}=(V / f)\left(\text { voUT }_{\mathrm{O}} / v_{\mathrm{IN}}\right) \\
b_{Y}=l_{y} / n \\
n=\alpha \cdot l_{y} \cdot f \cdot v_{\mathrm{IN}} /(V \cdot \text { voUT })\left(b_{X}=\alpha b_{Y}\right)
\end{gathered}
$$


$\alpha=1$ のとき情報抽出領域は正方形となる。

片ピッチのオートデンシトメータは， $X$ 方向 1 行ご との波形が順序正しく得られるため, 定性的な波形解 析に重宝がられている。自動処理の面から考慮すれば コンピュータ配列に規則正しく格納できる利点を有し ている。しかし，逆方向スキャンの間は無駄なデータ を記録することになるので注意を要する。

(b) 両ピッチ櫛型オートデンシトメータ

両ピッチ櫛型のデンシトメータは, 定性的処理を行 なら場合，片ピッチ型より計測時間を短縮することが でき無駄な波形を抽出することがない。しかし，スキ ヤン 1 行ごとの波形順序が逆になるためプログラム上 で配列変換を必要とする。片ピッチ型のサンプリング 数 $N_{X}, N_{X Y}, N_{x}$ 抢よび $N_{x y}$ に相当するサンプリン グ数 $\bar{N}_{X}, \bar{N}_{X Y}, \bar{N}_{x}$ および $\bar{N}_{x y}$ は次式で与えられる。

$$
\begin{aligned}
& \bar{N}_{X}=2\left(L_{x} / V+t_{0}\right)\left(v_{\text {IN }} / v_{\text {OUT }}\right) f \\
& \bar{N}_{X Y}=2 n\left(L_{x} / V+t_{0}\right)\left(v_{\text {IN }} / v_{\text {OUT }}\right) f \\
& \bar{N}_{x}=2 l_{x} \cdot v_{\text {IN }} \cdot f /\left(V \cdot v_{\text {OUT }}\right) \\
& \bar{N}_{x y}=2 n \bar{N}_{x}
\end{aligned}
$$

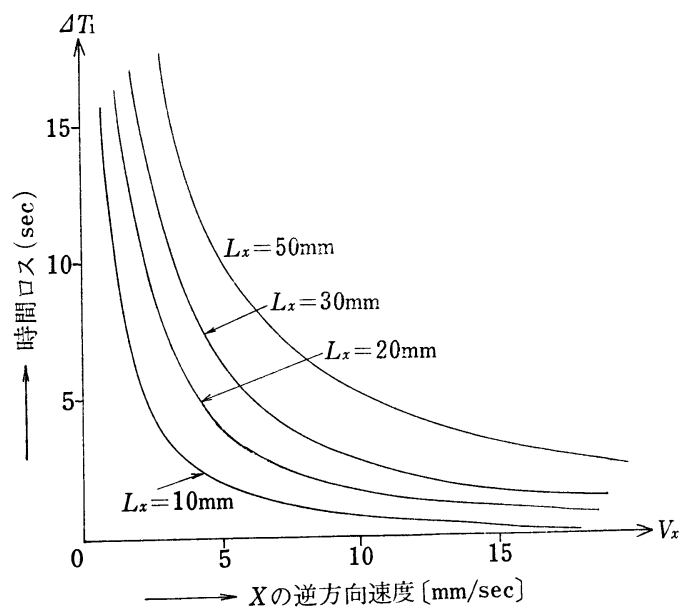

図-1 時間ロスと $X$ の逆方向速度の関係

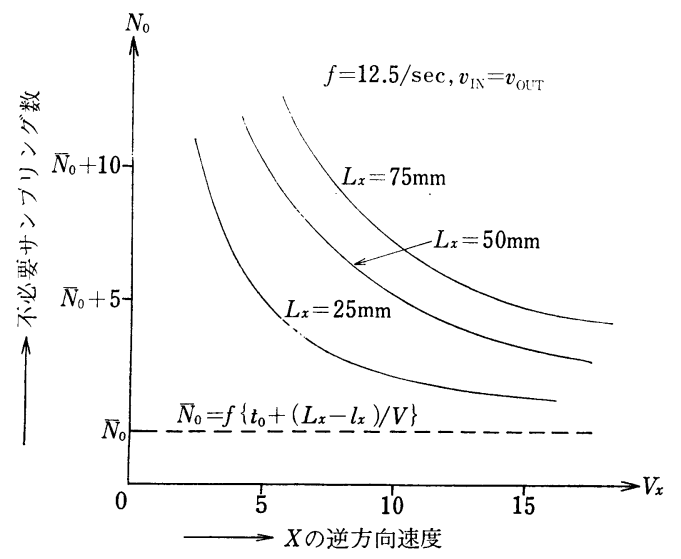

図-2 片ピッチ型の不必要サンプリング数
ところで，自動処理に和いて片ピッチ型と両ピッチ 型の差は，主としてサンプリング時間の問題と考えて さしつかえないので，両者のX方向 1 往復に費する時 間 $T_{1}$ 执よび $T_{1}$ の差 $\Delta T_{1}$ を求めた。

$$
\Delta T_{1}=T_{1}-\bar{T}_{1}=L_{x} / V_{x}
$$

したがって，片ピッチ運動をするデンシトメータを 使用の際には $\Delta T_{1}$ を最小にすべきであるから $V_{x}$ を 最大速度にすればよい。図-1 は，式(12)の $V_{x}$ と $\Delta T$ の関係を示したものであり, 図-2 は不必要サンプリン グ数 $N_{0}$ と $V_{X}$ の関係を示したものである。

\section{4. 色調別分布抽出}

\section{4-1-1 縮小資料の測定}

色分解を実施するには地図がかなり大きいので地図 を縮小しなければ処理機械で走査することが不可能な とさが多い。そこで文献 2）では，大阪土地利用現況

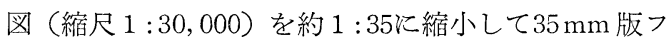
イルムに変換した。このカラースライドをスキャナー グラフの計測資料にして数種の連続階調ネガ写真を作 成し，この写真を片ピッチ型のオートデンシトメータ で波形抽出し，AD変換機により量子化し，FACOM 230-60で処理した。この結果，一部分のパターンに ついて 80 〜 90\%程度の抽出率を得ることがだきた。今 回はさらに抽出率を向上させる目的で下記の処理条件 を採用している。

（1）スキャナーグラフを 3 色分解機から 7 色分解機 に変更した。

(2) スキャナーグラフの原稿を $35 \mathrm{~mm}$ 版から $6 \times 9$ 版に変更した。

(3) サンプリング間隔を地上位置に換算して約 $1 / 3 に$ した。

これらの分布抽出条件のほかに標準メッシュに適応 すべく処理機械の計測条件を調ベたが，標準メッシュ に対応する機能がないため縮小資料の測定ではデンシ トメータの機能に添った適当なメッシュ間隔となって いる。

\section{4-1-2 工業地・商業地の抽出}

大阪府の土地利用現況図は，14種類（一般市街地, 商業地・工業地・衆落地・公園など・基地・社寺敷地 - 学校・田・畑・山林・原野・低湿地・水面）に区分 され，この中の有彩色は 12 種類, 無彩色は 2 種類であ る。またこのほか活字，道路などの線に無彩色を使用 しているため無彩的は 2 種類以上となる。これらの分 布から工業地 (青系色) と商業地 (赤系色) について のみ分布抽出を実施した。このときの抽出条件は下記 の通りである。 


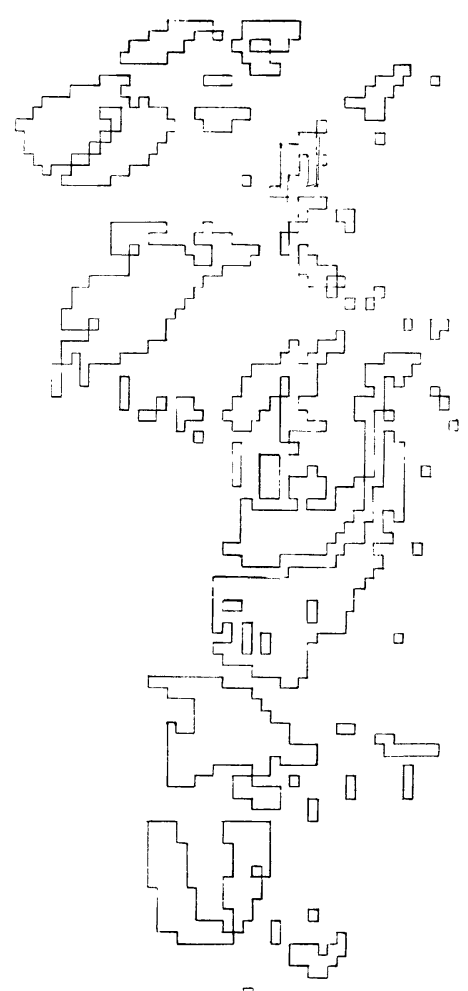

凸

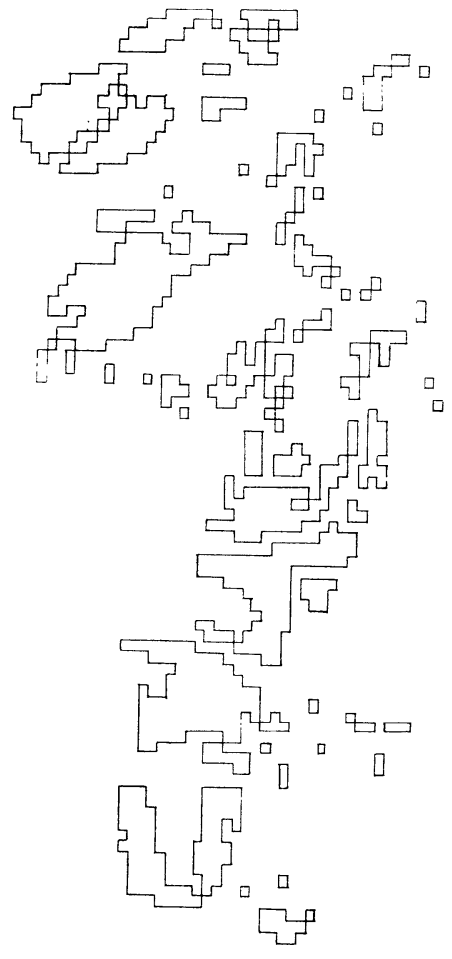

凸

図-3 工業地 $S$ 分布(地図パターン)

図-4 工業地 $\bar{S}_{1}$ 分布(抽出パターン)

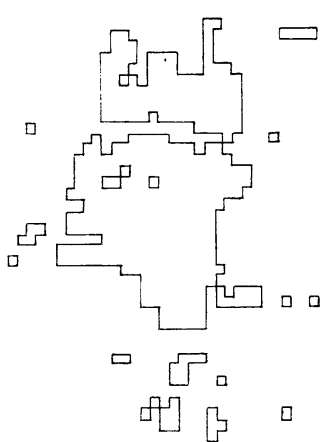

図-5 商業地 $S_{2}$ 分布 (地図パターン)

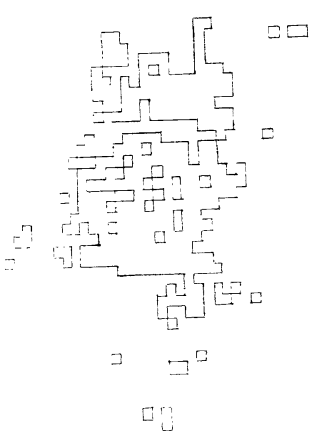

図-6 商業地 $\overline{\boldsymbol{S}}_{2}$ パターン

(抽出パターン)
(1) スキャナーグラフの計測資料は原地図（約100 $\left.\times 80 \mathrm{~cm}^{3}\right)$ をコダックカラースライド（縮小比 $1: 13.6$ ) $6 \times 9$ 版に和さめたものを使用した。

(2) スキャナーグラフの装査線数は, 500線/inch で ある。

(3) カラースライドと連続階調ネガ写真の寸法比 は, 1:1である。

(4) 濃度測定装置によって連絸階調ネガ写真を走査 した条件は， $V=20 \mathrm{~mm} / \mathrm{min}, V_{x}=1,000 \mathrm{~mm} / \mathrm{min}$, $b_{Y}=0.5 \mathrm{~mm}$ である。

(5) 連続階調ネガ写真の有効寸法は約 $76 \times 55 \mathrm{~mm}^{2}$ で あり，140×90個のサンプルを抽出した。

(6) $\mathrm{AD}$ 変換機のテープ密度が電算テープ密度と異 なるために多大な手数を要するので，ここでは濃度波 形から濃度電圧值を読取った。読取り值は10進 1 桁表 示であり，これを第 1 次マクロ表示と呼ぶことにす る。

上記条件の基で抽出された工業地・商業地パターン

表-1 カラースライドからの分布面積抽出率

\begin{tabular}{|c|c|c|c|c|c|}
\hline \multicolumn{3}{|c|}{ パターンの種類 } & $S_{i}$ & $\overline{S_{i}}$ & 抽出率 \\
\hline 工 & 業 & 地 & 418 & 390 & $93.3 \%$ \\
\hline 商 & 業 & 地 & 318 & 256 & $80.5 \%$ \\
\hline
\end{tabular}

注) $S_{i} \cdot \bar{S}_{i}$ の単位 $: 10^{4} \mathrm{~m}^{2}$
の分布面積 $\bar{S}_{1}$ と $\bar{S}_{2}$ とすると， $\bar{S}_{1} ， \bar{S}_{2}$ の面積抽出 率を求めるには地図の $S_{1}, S_{2}$ が必要であるから, こ れを原地図より手動で算出した。手動抽出は原地図に $140 \times 90$ 個の格子板をのせ，各メッシュ内の占有面積 が50\%以上のものを抽出した（第 2 次マク口表示）。

図-3は，地図上の工業地を手動で抽出した $S_{1}$ 分布 であり，第 2 次表示マクロ表示である。

図-4は，工業地を B.G.R. 法㐨よび B.W. 法によ り抽出した第 1 次マクロ表示值を第 2 次マクロ表示值 におきかえた $\bar{S}_{1}$ 分布を示したものである。

図-5 は，図- 3 と同様にして抽出された商業地の分 布 $S_{2}$ である。

図-6 は, 図-4 と同様にして抽出された商業地の分 布 $\bar{S}_{2}$ である。これらの分布面積抽出率を表-1に示 した。

一文献 2）と今回の抽出率を比較すると大差ないよう であるが，前回の抽出率は自動算出方法によったため 抽出されるべき位置で抽出しえなかった分布と抽出す ベきでない位置より抽出された分布が打消し合ってい た。このため抽出率の割合に比べて抽出パターンの形 状が地図パターンに類似していない部分がかなり多か ったといえる。

今回の実験は, 地㘠分布に相当するメッシュ位置に 
特いて抽出されているか否かを調査したものであり， 精度の向上が図-3〜6 を比較しても明らかである。

\section{4-2-1 地図の原寸測定}

地図の色調を利用して分布パターンを抽出するに は，地図上の印刷色によって分布抽出の可否を判定さ れるべきである。前述の縮小第 2 原図（カラースライ ド)による方法は，地図を写真に撮影するために，分 布抽出の可否を地図の色調ならびに分布状態以外に写 真処理からくる制限を加味して判定しなければならな かった。

上記の鑑定要素以外に第 2 原図を作成する手間とか 抽出の精度の問題などを考慮に入れると地図の原寸測 定の必要性が察しられる。そこで実験資料として文献 2)ならびに上述の縮小資料測定の原稿と同一のものを 使用することにし，スキャナーの計測寸法制限を考慮 して地図の一部分を切り取って実験することにした。 この切り取られた地図 (図-71) は，11種類の有彩色 と 3 種類の無彩色を含み, 約 $80 \times 300 \mathrm{~mm}^{2}$ (地上約 2.4 $\times 9 \mathrm{~km}^{2}$ ) の海岸線を含んだ堺市付近のものである。

この地図をスキャナーグラフで走査し（走査線数： 500 線/inch）パターン分布の種類ごとに連続階調ネガ 写真を作成した。このネガ写真の数種類を図-7(2)〜6) に示してある。また，図-7 (2)'〜6)は図-7 (2)〜(6)より抽 出した值を打出したディジタルマップであり, 図-7(1) は図-7(2) '〜6!のデータを総合して得られたものであ る。

このディジタルマップの抽出単位は, 標準メッシュ によるものであり緯度 3 "，経度 $4.5^{\prime \prime}$ の間隔で格子板 を作成し手動で各メッシュ内占有面積を 10 進法 1 桁表 示で抽出（第 1 次マクロ表示）した。

手動抽出をした理由は，図-7(2)〜6)から明らかなよ らに分布抽出がほぼ完全であり白と黒といら単純パタ ーンであるため B.W. 法によれば充分判別できるが， B.W. 法の処理時間と手数とがかかりすぎること，濃 度測定機の測定寸法制限などを考慮したためである。

\section{4-2-2 各パターンの抽出分布の算出}

各パターン分布の 連続階調ネガ写真から約 $80 \times 264$ $\mathrm{mm}^{2}$ を $I \times J=24 \times 80$ 個のメッシュ数で抽出し, 各メ ッシュ内の各分布の種類の占有面積（第 1 次マクロ表 示）を $A(I, J)$ で表わすことにし，K個のネガ写真 より $K$ 個の $A(I, J)$ が求められる。したがって, 電 子計算機処理では $A(I, J, K)$ の 3 次元配列ですべて のデータを取り扱うことにした。よって，I，Jは抽 出位置を，Kはパターン分布の種類を表わすことにな る。このとき下記の関係式が成立つ。

$$
\begin{aligned}
& \sum_{K=1}^{r} A(I, J, K)=9 \\
& \bar{S}=\beta \sum_{I=1}^{n} \sum_{J=1}^{m} \sum_{K=1}^{r} A(I, J, K) \\
& \mathrm{s}_{K}=\gamma \sum_{I=1}^{n} \sum_{J=1}^{m} A(I, J, K)
\end{aligned}
$$

ただし， $\bar{S}$ ：分布抽出の全面積

$s_{K}$ : 各パターン分布別の面積

$\beta \cdot \gamma$ : 換算定数

である。

式(13)〜（15）を利用して計算される分布面積は各パ ターンごとの総面積であり，単に総面積だけを算出す るのであれば自動面積計に連続階調ネガ写真を走査さ せればよい。しかし，各パターンのある一部分につい ての求積を要求された場合, 自動算出が困難である。 そこでこれらの要望に答えるため等高線作成プログラ ムを改良して部分面積の算出プログラムを作成した。 図-8は, 図-7(3) のデータの一部分より $A(I, J, K)>5$ (このとき工業地は $K=3$ である）の部分をコンター で示し，コンター上に番号を記入させ，コンター番号 と面積值とを対応させた。

また，図-9は，図-8に使用したデータから隠線消 去による透視図を作成したものである。この透視図 は，ディスカッションやシミュレーション特よびデー タ再生時の全容観察に適用されるならば効果的と思わ れる。ここでは, これらの図形表示を第 3 次マクロ表 示と呼ぶことにする。

\section{4-2-4 メッシュ法における諸問題}

メッシュ法を利用して地図の各パターンの占有面積 を算出する方法には種々あるが，ここでは下記に示す 4 種類の方法で求積し, メッシュの位置のずれについ ても検討した。

（1）第 1 次マクロ表示による抽出法（抽出值 $\bar{S}_{i}$ )。

(2) メッシュ内の最大占有面積のパターンを格子内 の代表とする抽出法 (抽出值 $A$ )。

(3) 第 2 次マクロ表示による抽出法（抽出値 $B$ )。

(4) メッシュ交点あるいは格子中央点のパターンを 格子内の代表値とする抽出法 (抽出値 $C$ )。

(1)の方法は，4 種の方法の中で理論的にも格子の状 態や分布の状態のいかんにかかわらず地図のパターン の分布に最も近似した分布を抽出することができるも のであるから，ここでは基準值として取り扱らことに する。

(2)の方法は, 第 2 次マクロ化の簡便法であり, 第 2 マ クロ表示の代用として使用可能か否かを調査する目的 で求積した。(3)の方法は，(1)のデータを使用した 2 進 1 析表示のため一般には四捨五入法により 0 か 1 に区 


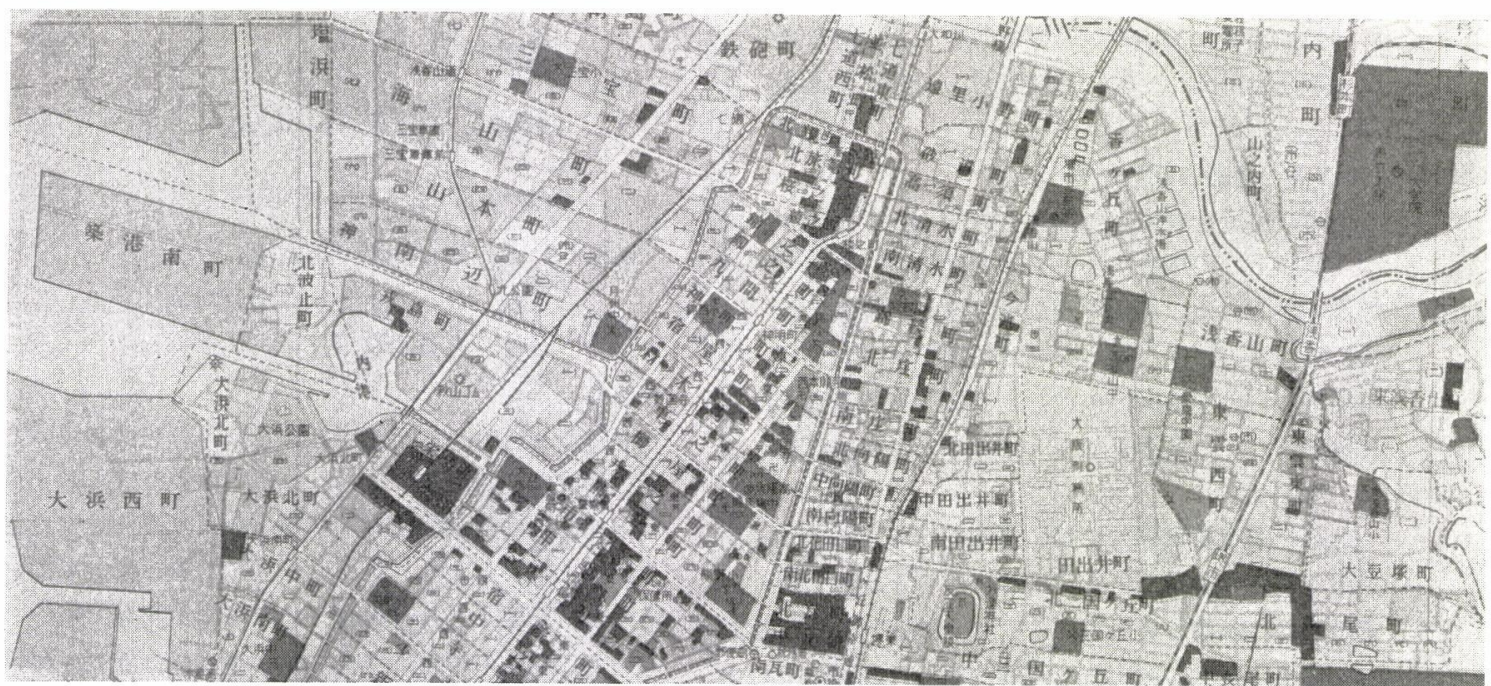

図-7 (1) 堺市付近の土地利用現況図（縮尺 $1 / 3$ 万 $\times 3 / 4 ）$

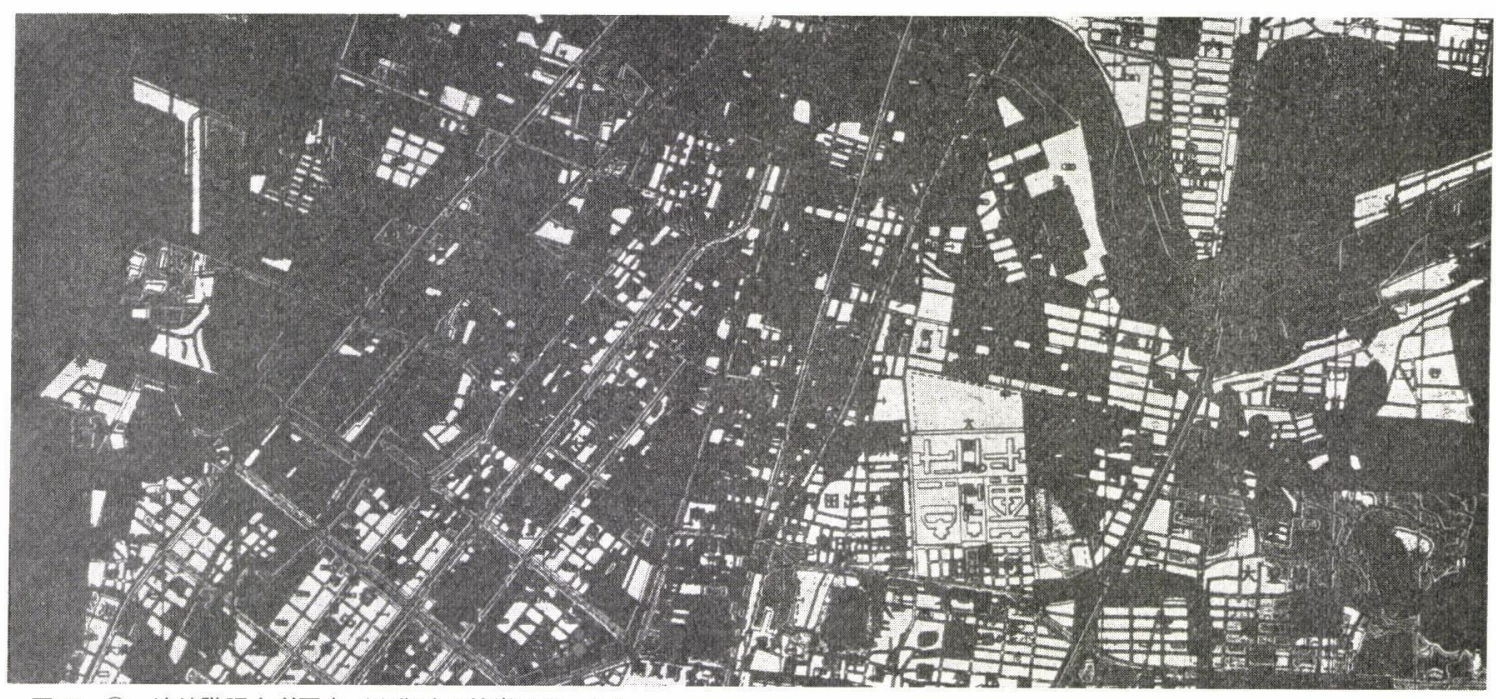

図-7 (2) 連続階調ネガ写真（市街地の抽出パターン）

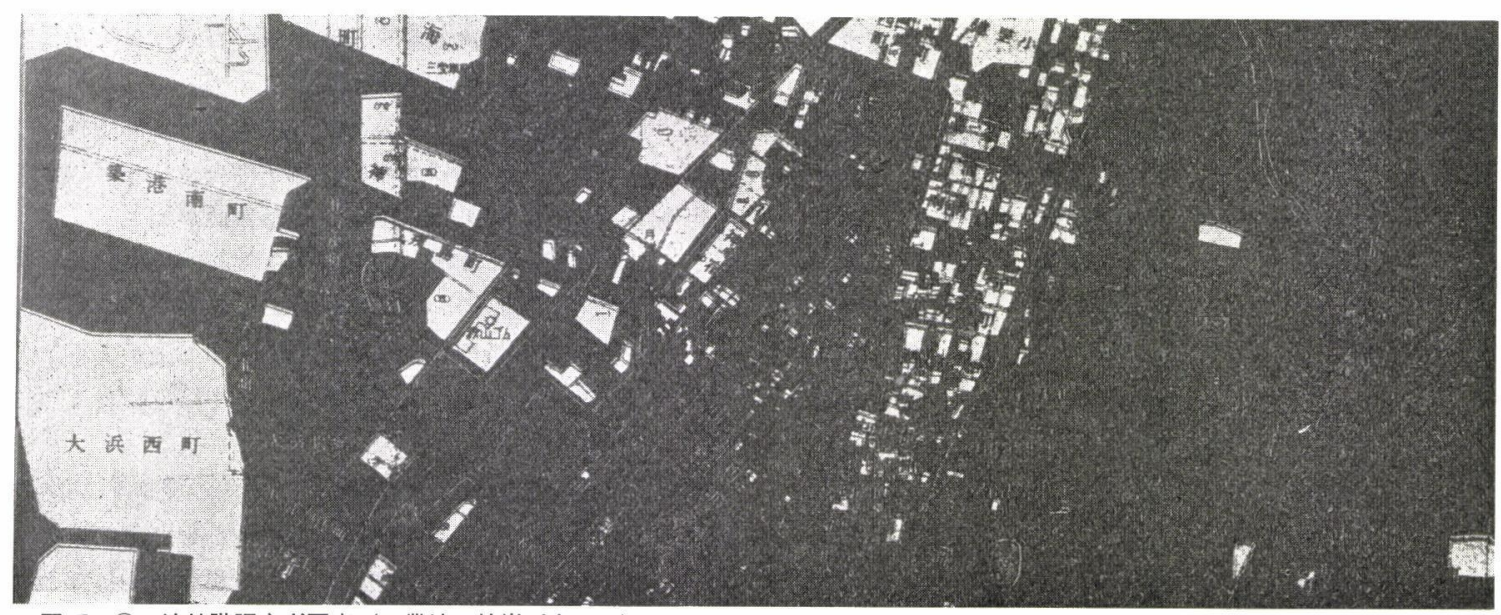

図-7 (3) 連続階調ネガ写真（工業地の抽出パターン） 

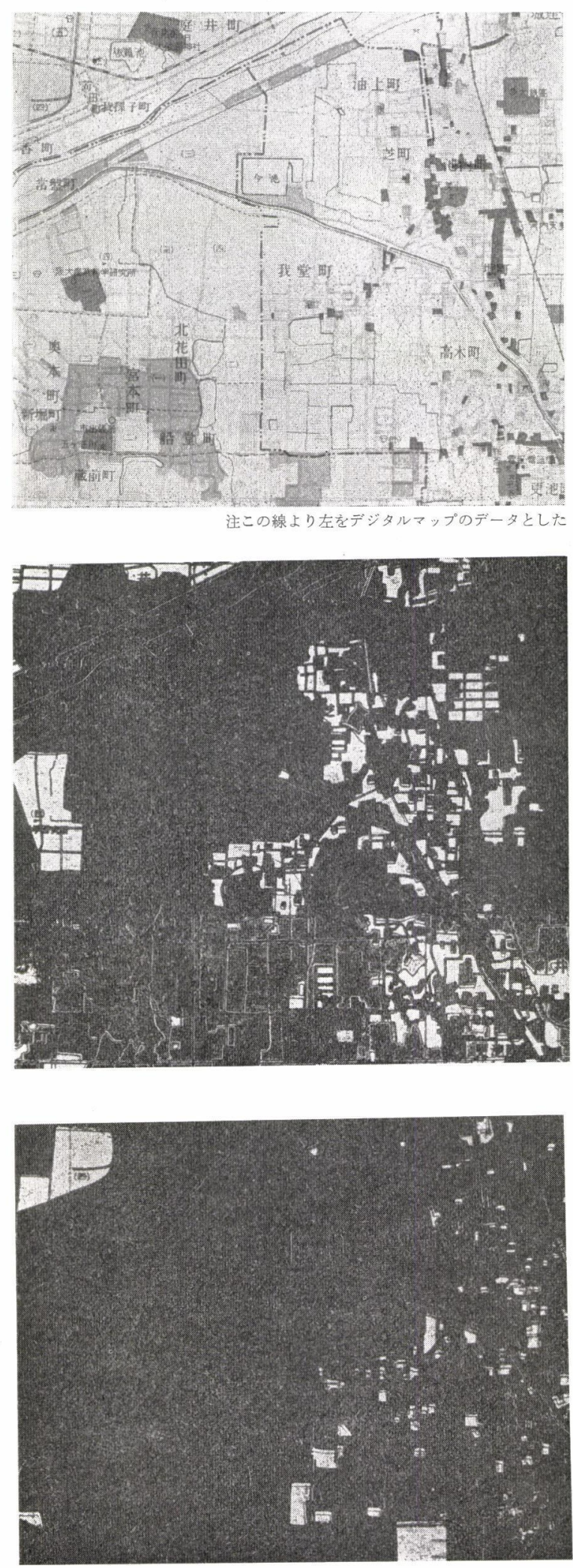

別すればよいが，分布状態によって四捨五入法の適用 性を考慮しなければならないと思わ机る。そこで四捨 五入法と三捨四入法に上る抽出変動を調査した。表-2 の $B_{5 i}{ }^{\prime}$ は, 四捨五入法, $B_{4 i}{ }^{\prime}$ は三捨四入法に上る分 布抽出率である。四捨五入法に上る総占有分布面積百 分率は常に100\%に満たないため，100\%にした占有分 布面積百分率が $B^{\prime}$ 分布である。(4)の方法は, 格子中 央点（あるいは格子交点）にあるパターンの種類でも って格子内を代表する方法であり, パターンを手動で 抽出する場合の簡便法である。したがって，この(4)法 による $C$ 值と $\bar{S}_{i}$ 值の較差から $A$ 值, $B$ 值を評価する ことができる。また(4)法の $C$ 值は, メッシュ位置のず れによって抽出パターンの種類が変化するため, 変動 率を調查しておく必要がある。変動率は, メッシュを メッシュ間隔距離以内で移動させることにし，3 種の 移動抽出值 $c_{1}, c_{2}, c_{3}$ を求め $c_{1}, c_{2}, c_{3}$ の算術平均を $C$ 値とし $C$ の 1 測定の平均二乗䛊差 $\varepsilon_{c}$ を求めた。

以上の分布面積 $\bar{S}_{i}, A$ 出よび $B$ 值より求めた占有 面積百分率を緃軸に，横軸にパターンの種類を取りプ ロットしたものが 図-10で西る。図-10 の折線は，A と $C$ の較差 $\varepsilon_{A C}$ を求め $A$ 值の占有面積百分率を中心に 占有面積百分率に 換算された $\varepsilon_{A C}$ を上下にプロッと し、これらのプロット点を結んだものである。したが って, 折線内に含まれる $A$ 值の占有面積百分率 $A^{\prime}($ 印) と $B$ 值の占有面積百分率 $B^{\prime}$ 印) は手動簡便法 より抽出精度が高いことを意味する。

\section{5. 分布抽出と抽出率の考察}

この研究で使用している分布抽出法のシステムに は， B.G.R. 法と B.W. 法を必要としているが，本来 資料の色調を判定するには B.G.R. 法の久で抽出可能 である。しかし，色分解の状態を定性的化確認するた めには連続階調ネガ写真を中間媒体として利用した方 法が安全であった。上述した実験から抽出状態も良好 であり，B.G.R. 法により抽出された 3 要素を直接 $\mathrm{A}$ $\mathrm{D}$ 変換しコンピュータ処理してもさしつかえない段階 にきたといえる。

また，パターン分布の抽出率については原寸地図の 測定の方法が有利であり手数がかからない特徵があ る。縮小する方法は，コンパクト化による多種多様の 利点を有し, 両者をマクロからミクロ調査に応じて使 い分ける之よい。

分布抽出の抽出率を左右する主要因は, 実験の結果 メッシュ間隔とサンプリング時のスリット間隔である とい光, 抽出されたデータ表示方法によって抽出率が 微量変動するため, メッシュ間隔とスリット間隔を同 一にし，上記の第 1 次マクロ表示をすることが，地図 


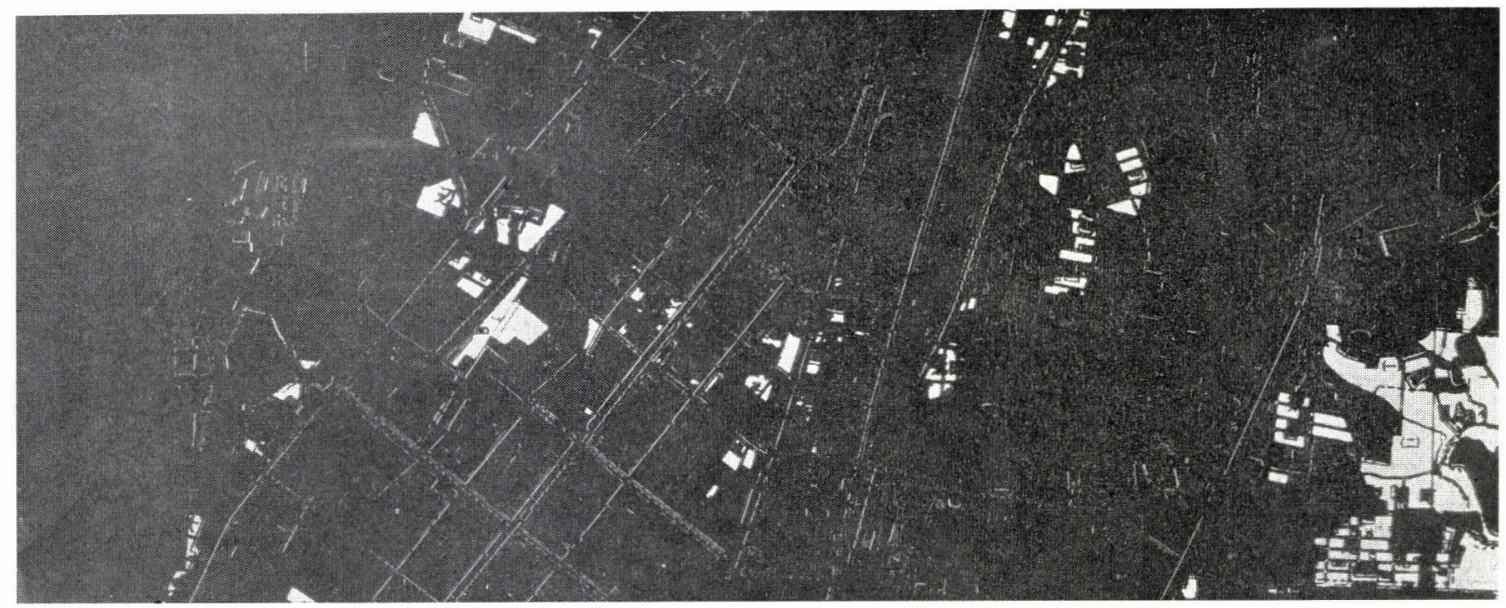

図-7 (4) 連続階調ネガ写真（田地の抽出パターン）

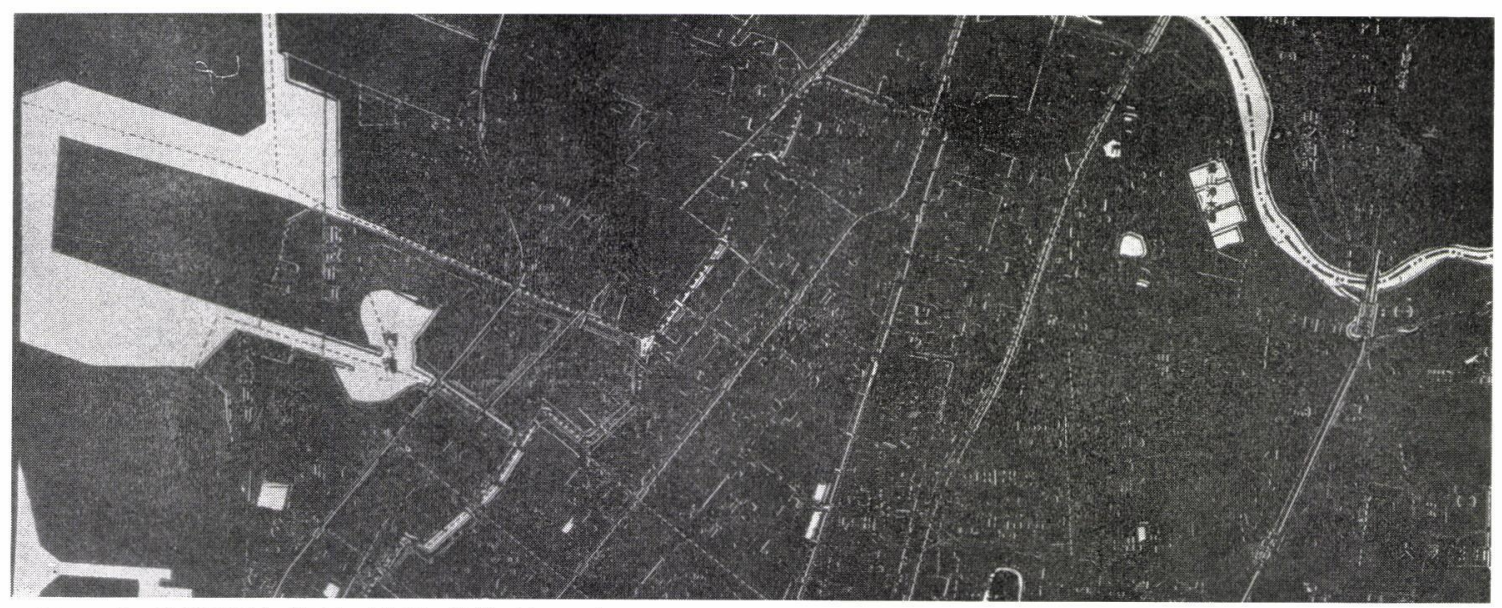

図-7６連続階調ネガ写真（水面の抽出パターン）

表-2 種々の方法による占有面積率比較表

\begin{tabular}{|c|c|c|c|c|c|c|c|c|c|c|}
\hline \multicolumn{4}{|c|}{ パターンの種類 } & \multirow{2}{*}{$\begin{array}{l}S_{i}^{\prime} \\
22.72\end{array}$} & \multirow{2}{*}{$\begin{array}{l}A^{\prime} \\
26 . \subseteq 3\end{array}$} & \multirow{2}{*}{$\begin{array}{l}B_{5 i^{\prime}} \\
20 . \mathrm{C} 3\end{array}$} & \multirow{2}{*}{$\frac{B_{4 i^{\prime}}}{26.51}$} & \multirow{2}{*}{$\begin{array}{l}B^{\prime} \\
27.73\end{array}$} & \multirow{2}{*}{$\frac{C^{\prime}}{26.55}$} & \multirow{2}{*}{$\begin{array}{l}\varepsilon_{C^{\prime}} \\
\pm 0.78\end{array}$} \\
\hline (2) & 甫 & 街 & 地 & & & & & & & \\
\hline (3) & 工 & 業 & 地 & 16.93 & 19.32 & 14. 50 & 17.86 & 20.03 & 17.59 & \pm 0.26 \\
\hline (4) & 田 & & 地 & 16.05 & 18.49 & 15.26 & 17.40 & 20.52 & 18.74 & \pm 0.52 \\
\hline (5) & 低 & 湿 & 地 & 9.43 & 9.22 & 5.89 & 10.16 & 7. 92 & 9.42 & \pm 0.63 \\
\hline (6) & 水 & & 面 & 8.08 & 6.83 & C. 04 & 7. 19 & 8.12 & 7.81 & \pm 0.47 \\
\hline (7) & 畑 & & 地 & 4.87 & 5.78 & 3. 18 & 4.69 & 4. 28 & 5.26 & \pm 0.21 \\
\hline (8) & 商 & 業 & 地 & 3.63 & 3.07 & 1.35 & 2.24 & 1.82 & 4.01 & \pm 0.36 \\
\hline (9) & 学 & & 校 & 2.96 & 3.65 & 2.24 & 3.18 & 3.02 & 4.89 & \pm 0.31 \\
\hline (10) & 衆 & 落 & 地 & 2.64 & 2.29 & 2.50 & 3.02 & 3.36 & 2.66 & \pm 0.10 \\
\hline (11) & 公 & & 園 & 1.29 & 1.35 & 0.68 & 1.04 & 0.91 & 1.46 & \pm 0.31 \\
\hline (12) & 社 & & 寺 & 0.87 & 0.52 & 0.10 & 0.26 & 0.13 & 0.57 & \pm 0.16 \\
\hline (13) & そ & の & 他 & 10.53 & 2.50 & 1.61 & 1.82 & 2.16 & 1.04 & \pm 0.90 \\
\hline & 今 & & it & 100.00 & 100.00 & 74.38 & 95.37 & 100.00 & 100.00 & \pm 0.51 \\
\hline
\end{tabular}

注）(11その他は，白色以外の無彩色バターンであり境界線，活字，道路，鉄道などを含んだものであるため抽出精 度が低い。 

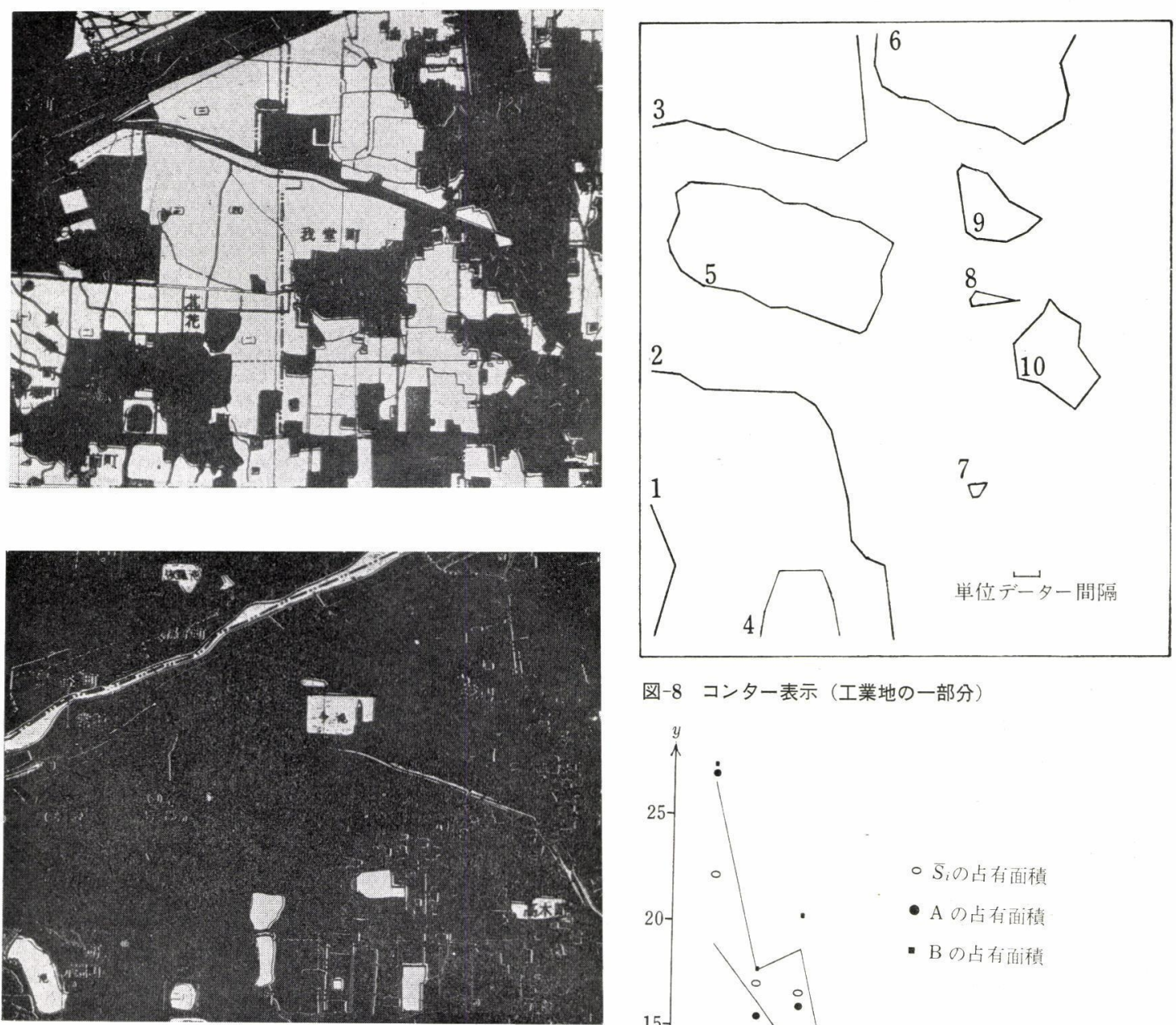

図-8 コンター表示（工業地の一部分）

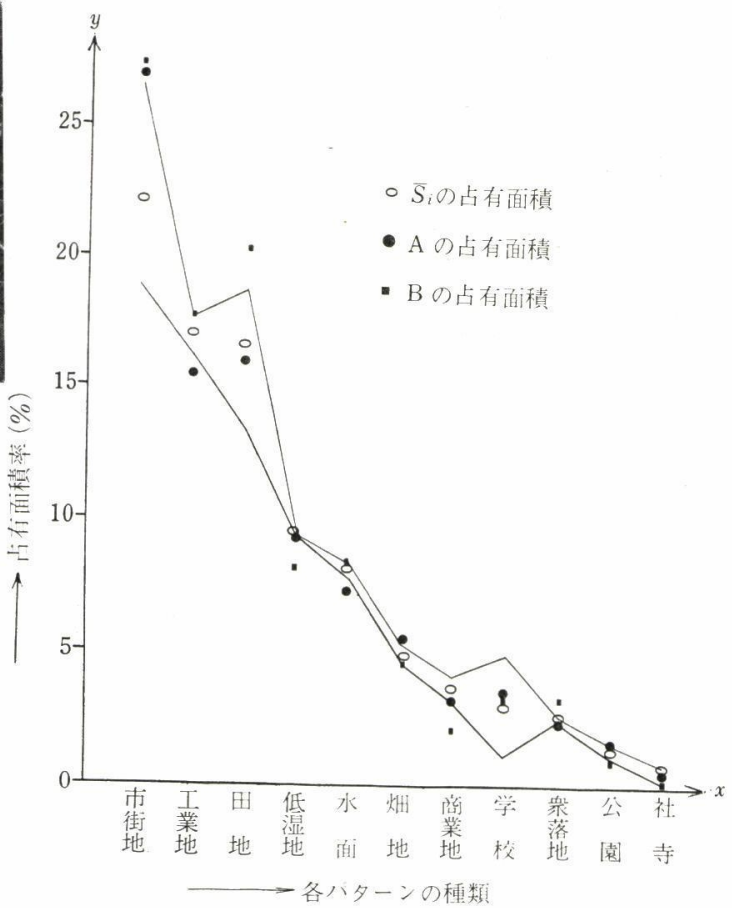

図-10 地図パターンの分布状態

図-9 隱線消去による 透視図（工業地 の一部分)

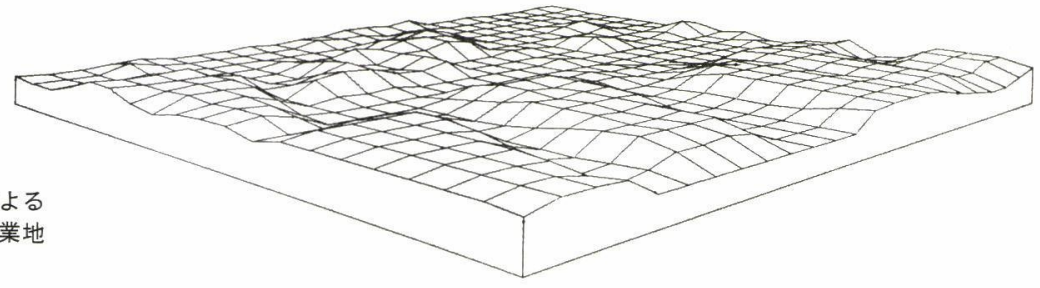


NO. 1

UU1,

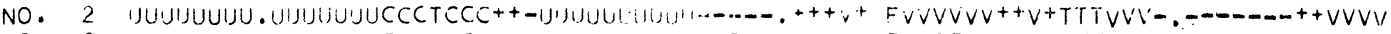

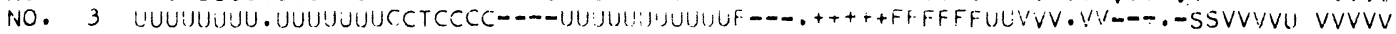

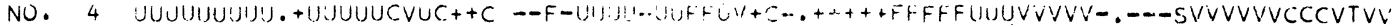

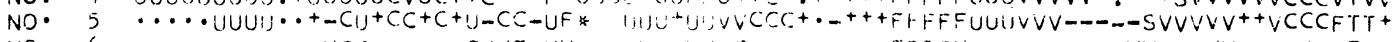

NO. 6

NOי

ND. 8

NO. 9

NO. 10

NOP 11

NO. 12

NO. 13

NO. 14

NO. 15

NO. 16

NO. 1.7

NO. 18

NO. 19

NO. 20

NO. 21

NO. 22

NO. 23

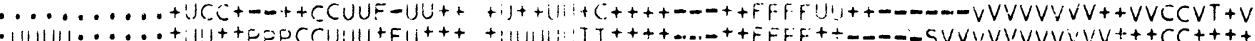

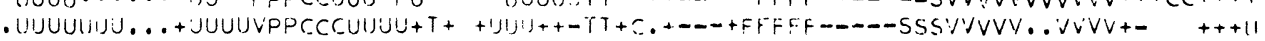

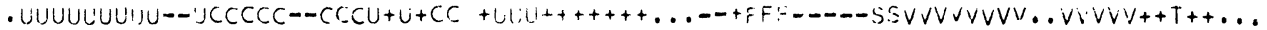

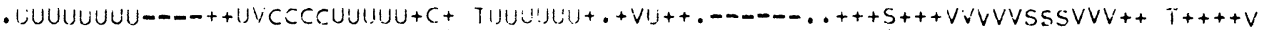

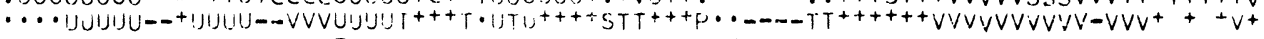

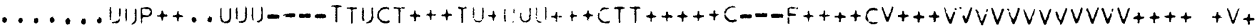

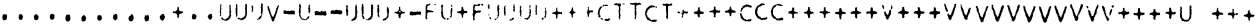

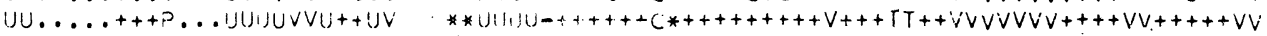
JUUUUUU⿴囗十 UUUUUUJU--PPPV CC-V-U+-P--+UTTVUUU! $C++++++C C C C+-V V$ SVFVVVVVVVVVVVVVVV+.U+UVVVV+UUVV/

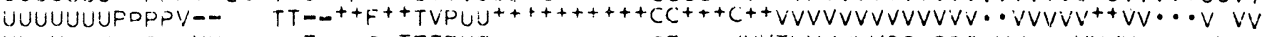

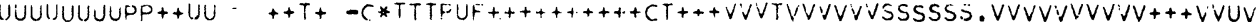

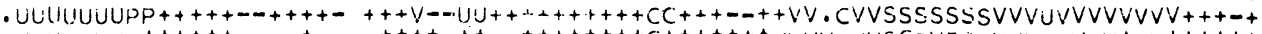

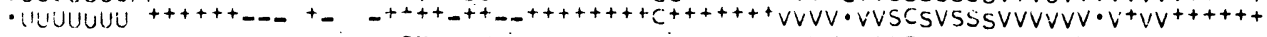

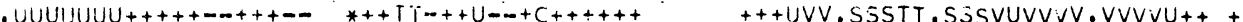

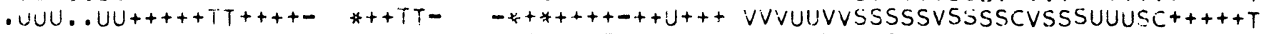

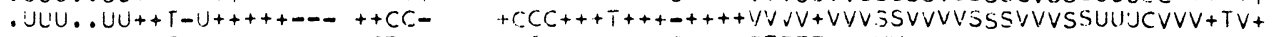

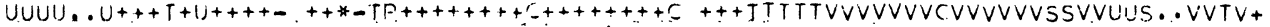

図-7 (1) $^{\prime}$ 堺市付近の土地利用分布のデジタルマップ

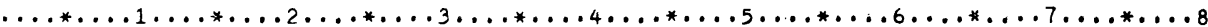

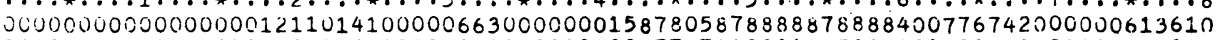
00000000000000000110012560000000000000000047747440001047633100000100000000431210 00000000021000001210100223000010000010200007877500000000100000000000000000010000 $00000 \mathrm{C} 00037410001111763320300011300300032003877600000000000000000000000110003000$ 00000000000600061053410222113210444322044340077700000300310000000000005412003014 00000000000701171187000022236534156103074770038700000256410000000000008522003362 00000000000703771022020031157636101210146470018500017731000000000000004676246584 0U0C000000060022000011023:j644252134823360051017300014000000000000000000521236651 $0000000 C 011101200001330130633051104446575233105200000023000000000000000364475011$ 000000000212133000010000118232201311.17352143000000001675278400000000000663065540 00000000021610000001300002757121125369000667110000001674498.3000000000203 .34243416 00000000015700000110121114374234112568222487751000244883078500000000000034662627 00000004203610002200001014320312100677310214754144765885047710000000000433532557 $000000376522100 C 000 C 233112221111000589886425655587761888007810000035556315334413$ 000000047501011001.01540122141131014579895001585457512343047600000356554000636300 00000000120122211102423014210322211468785104430013421000000000000060383000262200 001000000103221000000263264100034567778786016550642110000000000000030073002010121 000000004277000005426300120013245776,58787004360032010000000000000022110004663202 00000000235755501664612456202224677778887016361155000000000000000000000000047415 00000000475776403335331376432541176648567365555672000000000000000000001501467565 00000000776751056523101553233422362335555320023874010000000000000000013400454344 00000000556753386751013661103022340477546546774431013000000000000000011103555443 00000000443316575822203330000036310576277738776001343000000000000000000000225024 00000003651337757305520124566656436667677600353000320000002310000000000012000046 (2) 市 街 地

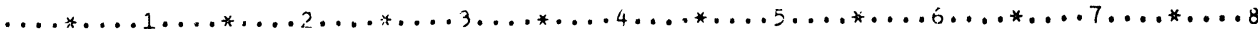
677777774776359940011000336994,1912000000000000000000000000000000000000000103100 $39999999499598880100001 \% 12727767759740600000000000000000000000000000000001103100$ 99999999463999892000001132476947599778100000000000000466300000000000000028200000 36809949501584801141001020093735198334600001000000000697200000000300010013000000 00024799500002620012250200400127443345000000000000003688100000000000000130010013 )$. $0698631000 j 1950070010559923310007774650605050000000002000000000000000000210100100$ 06949956420289742006026457111125761011000600000000000000000000000000000011100023 07948989967043340001004418000095493320610000503000000000000000000000000000101000

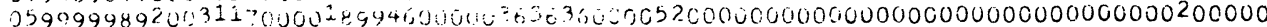
0013589992 1665510310884610023251,3230000020000000000000000000000000000001230010 00000025510000586121200610.03433545076500000000000000000000000000000001200011100 $00000002190008 \div 1233044500125565190000000000000000000000000000000003321050000$ $8632221022090067 \% 4035014101016344219000000000000000000000000000000011210220210$

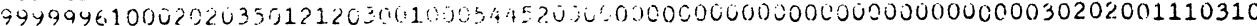
99999993000001000014000003310054420030000000900000000000000000000000303100003300

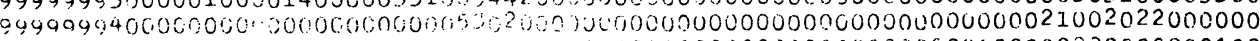

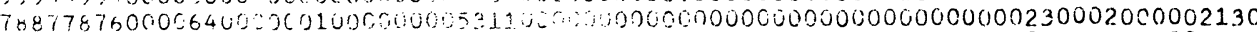

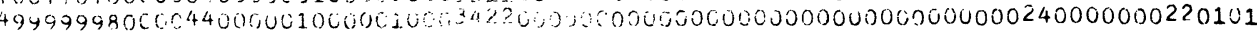

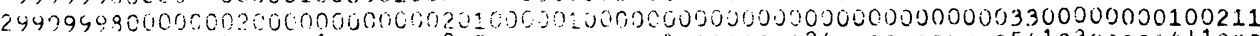

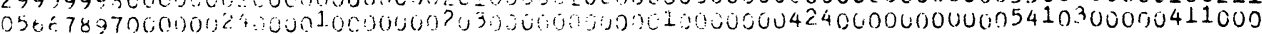

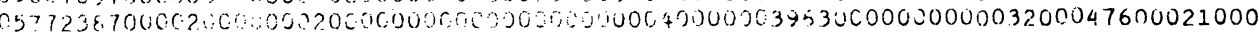
394620760200710000010010000005000000000000003000010020000000000000053700000002 $649920 \div 2003140600116000010(i), 0920000009010000000000000000000000035401200000$ 


\section{(4) ${ }^{\prime}$ 国地}

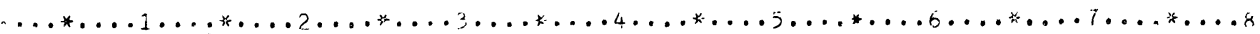
0000000000000000303320000000000.00000000008403000030030002511211000000 .051073

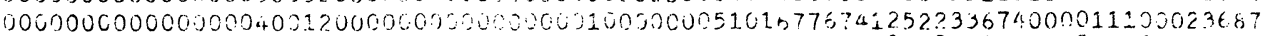
$000000000005000001,0000000(10100,0011110000000000000131365275310001389933048894$

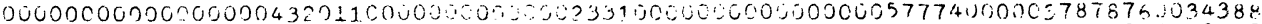

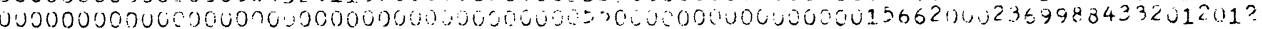

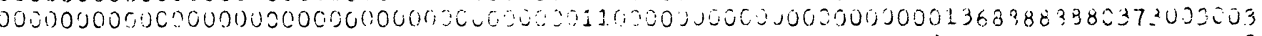
$0000000000003000 ? 000000006000000000009006001000062000000000286 \times 96590485000000003$

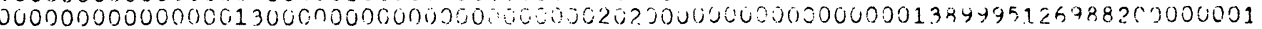
$00000000000500001000000000000001,00032003 ? 00500005000000147777774025889402000003$

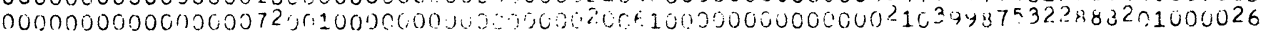
$00000000000000000254500000000000,00029000000900000000200494898877426441000) 52$.

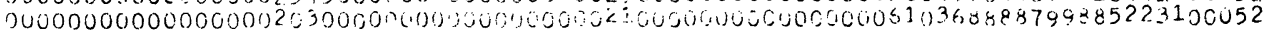

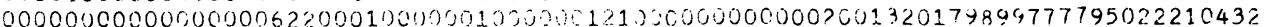
00500000000530000055001330000010002100050000000050005000000079899753220372200155 0000000000015000027521211000321100100000000000503173435622375785500031895100173

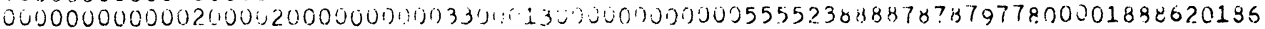
00000000000300000000000000051100012010007000002035548065878665238735012862114037 000000000000000000000000010001000000000000515730975906209100155637776993103223

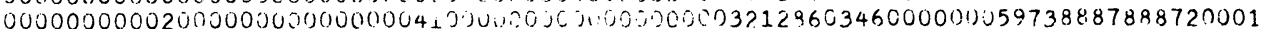
$00000000000000000600000000 \mathrm{~L} \mathrm{i} 0000000000200011007774155000400065480727297330000$ $0000000010000000000000000110000 \% 200000 j 0 \% j 00000013344020002120394466526485000300$

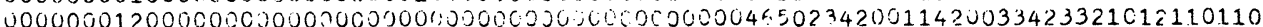

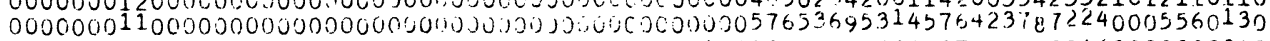

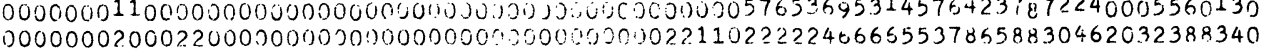

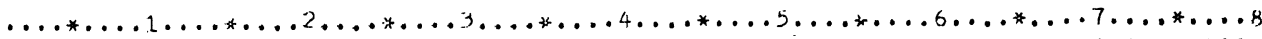
00000000300000000000000000000000124654456300000000000000000000000002561000000000

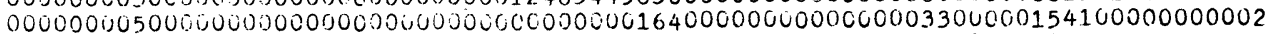
00000000510000000000000000000000000000000170000000000000001521003410000000000000 $131000004610000000000000000^{121} 00000000000063000000000000000002431000000000000000$ $999732004081000000000 C 0000 ? 01210 C C 000300045000000000000000023100000000050000000$ 47899985899000000000000000110003100001360023000000000000001330000000000000000000 930136.89999100009000000002110001000000001413000000000000232500003100000000000000 9300000357910000000000000200000100002000184300000000033.3201110003773000000000223

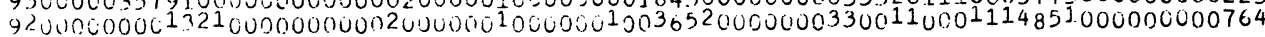
94000000000102210000000020000011000000510111410033355101106000001121000000000010

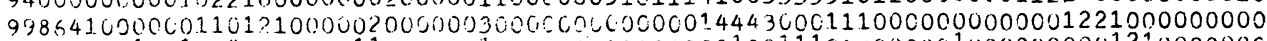
$9499997410019820000000110000001000 \mathrm{c} 000000000001001110000000010000000001210000000$ 99999955565338000000022000000510300000600000001210000000000000000000000011100000 1367775000367700000022600000030000005060000000050000000000000000000000000110000 50000090000296410000,010000000100000000000000000000000000000000000000000000010000

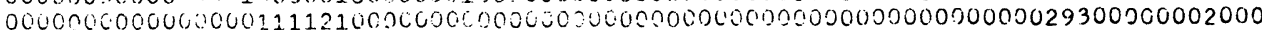

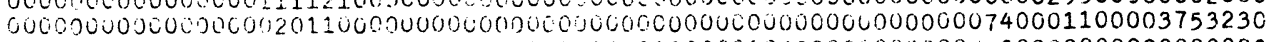
$20000000000000002100400000600000050 j 00000000000000000000000520000000000000223$

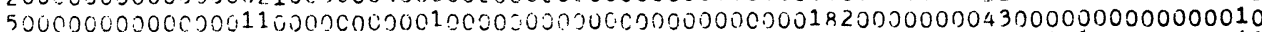
7000000000001.330000000000000000000500000000000000004600000000420010170000000011 $9433210000001110 \% 10000000000000,2020000000000000001930000600100010160000000001$ $9+2276000000200000000000000000006290000000500000020410000320000000020000000000$ 600079220603000000000000.3000000003606000000000011000000003100000000000000000000 3000792000020000030000009060)000000100000000000000000000001000000000000004410000

図-7

(6) 水 面

のパターン分布に最も近似した值を得る結果となる。 パターン抽出の簡便法としては，第 2 次マクロ表示 を使用すればよい。ただし，この方法を使用する場 合，格子内の占有面積が単に50\%を境にして区分する ことは危険であり, 地図パターンが非集合で点在すれ ばするほど境界を50\%より低下させねばならない。ま た，格子内の最大占有面積のパターンを格子内の代表 值とする方法も簡便法として充分使用できると思われ る。

メッシュの移動による抽出率に及ぼす影響について は，4-2-4 の(4)方法 ( $C$ 值)のバラッキから明白なよう に，このバラッキの影響が $\varepsilon_{A C}$ と比較して小さいから 抽出率を左右する主要因子としてメッシュ位置のずれ を考慮しなくもよいといえる。
つぎに，データ保管について述べれば，メッシュ内 を占有百分率で表現する方法は，地図のパターン状態 やメッシュ間隔に関係なく正確であるから，占有百分 率を10段階で表示し 0〜9の文字で格納するのが最適 と考え, 第 1 次マクロ表示を推める。保管データと共 に記録すべき必要事項 (配列最大值・原稿名・月日・ メッシニ寸法など）を順序を定めてデータの頭に記録 するとよい。保管データの再生については，第 3 次マ クロ表示（コンター図，透視図など）を用意すること により定性的なデータ分布状態の判定に役立ちえるも のとわれる。また，重㪄打手法によるディジタルマッ プは，濃度という概念を再生することができ，データ と図面の順換性を保つことになる。 


\section{結言}

地図の情報を抽出することは, 地図利用の面で有意 であり, 地図の単純利用の 1 方法として色調別の分布 抽出を実施し，B.G.R. 法と B.W. 法によればこれが 可能であることを実験的に実証してきた。しかし，地 図の 1 種である土地利用現況図の土地利用パターン分 布を精密に抽出したとしても, 地図印刷の原稿は人力 によるものであり原稿自体の精度が問題となってく る。さらに土地利用の 1 つである公園と名付けられた 地域の面積を正確に抽出したとしても，地図上の公園 と実際に必要な都市計画要素の公園とは異なった意味 を持つことがあり, 地図分布の抽出值がぞの程度の利 用価値を発揮するかはなはだ疑問な点もある。また， 地図は地上の位置とその特性を主として把握するため のものであり, データ抽出の精度の面から考察すれ ば，地球表面の位置特性をより密に記録した航空写真 からのデータ抽出値の方が地図からの抽出値より高精 度の值を得ることができ，さらに簃密なデータ抽出値 を要望されるならば，現地調査に頼らねばなるまい。

したがって, 本研究は調査用データ抽出の, 精度向
上といら目的も含まれているが，抽出率を明らか飞す ることによってマクロ調查用の 1 方法を開発した点に あると思われる。

また，ここで記載した処理システムは，分布パター ンの調査を 1 枚の地図により把握しデータ保管すると いら意味より，年代別地図からのデータ保管によって 年代的な土地利用パターンの調査をするのに有効であ る。この処理システムに使用した機械は，接続部分に 問題があり不必要な労力を費している。今後のデータ 抽出の実用化にたいしては，B.G.R. 法の処理機械と コンピュータの一体化を著者は望んでやまない。

最後に本研究費の一部は, 文部省科学研究費による ものであり，資料作成の一部は大日本スクリーンの津 田・鈴木氏に協力を得たことを追記して拈く。

\section{参 考 文 献}

1） A・ローゼソフェルド(石田・島村・佐薙訳)；“電子計 算機による画像処理”，共立出版，p $24 \sim 31$, 昭和 46 年 4 月。

2）星仰；“連続階調ネガ写真による一部の 色調パタ ーン認識”，写真測量，Vol.10, No.4, p.1～6, 1971。

3）星仰；“写真測量による情報処理と公害調査”, 公 害之対策，Vol.7, No.11, p. 19〜25, 1971 。

\section{8年度国際会議のおしらせ}

今年おこなわれる国際会議の予定は下記のようです ので，特しらせします。

1. Ninth International Symposium on Remote Sensing of Enviroment, April 15 19, 1974

(旧) Willow Ran Laboratory Michigan University

(現) Enviroment Research Institute Michigan State

2. Radar Remote Sensing for Geoscientists University of Kansas, July 23 27, 1973

3. Image Processing, Coding and Transmission, April 30 May 4, 1973
Purdue University School of Electrical Engineering

4. Training Course for non U.S. Scientists June, 1973

Mr. D.L. Kulow, Chief User Assist. Program EROS DATA Center Sioux Flls, South Dakota 57198 Geological Survey U.S. Department of the Interior

5. Summer School, Remote Sensing of Earth Resources, Tarbes August 21 September 21, 1973 Centre National D’Études Spatiales

Départment des Affaires Universitaires 129, rue de l'Université-75327 Paris Cedex 07 (Phone: 551.49.39-Ext. 470) 